fuels which will affect substitution. "We will be attacked by economists" admits Leach. The report has adopted apparatus replacement rates of some $5 \%$ per year after the new technology becomes available. Thus heat pumps have a $15-20 \%$ penetration of the market by 2000. But in housing the report allows until 2010 before all houses have 4 inches of loft insulation, and cavity walls are filled.

So far, the Department of Energy response has been friendly, and mildly defensive. "My feeling is that there is a lot of work to do yet in conservation in our methodology" said a spokesman. "We are only scratching the surface .. . But has Gerald Leach only taken the most favourable answers from all his inquiries? In our last green paper we took advice from the department of transport, the oil companies, and car manufacturers among others. Most thought that $20 \%$ conservation was ambitious. $\mathrm{Mr}$ Leach is applying current best practice across the board, and concludes that one can increase that 2 or 3 times. That may be wishful thinking."

The team responsible for the IIED report consisted of Gerald Leach, Christopher Lewis, Frederick Romig, Ariane van Buren, and Gerald Foley.

Robert Walgate

\title{
... and the view from across the Atlantic
}

\begin{tabular}{|c|c|c|c|c|}
\hline \multicolumn{5}{|c|}{$\begin{array}{c}\text { Forecasts of US primary energy demand in } 2000 \mathrm{AD} \\
\left.\text { (in quads }=10^{15} \mathrm{BTU}\right) \\
(1975 \text { consumption } 75 \mathrm{q})\end{array}$} \\
\hline \multirow[t]{2}{*}{ Year of forecast } & \multicolumn{4}{|c|}{ Source of forecast } \\
\hline & beyond the pale & heresy & $\begin{array}{l}\text { conventional } \\
\text { wisdom }\end{array}$ & superstition \\
\hline 1972 & 125 & 14 & 16 & 190 \\
\hline 1974 & $\begin{array}{l}\text { Lovins } \\
100\end{array}$ & $\begin{array}{c}\text { Sierra Club } \\
124\end{array}$ & $\begin{array}{c}A E C \\
140\end{array}$ & $\begin{array}{c}\text { Fed Power Comm'n } \\
160\end{array}$ \\
\hline 1976 & $\begin{array}{c}\text { FF (Zero growth) } \\
75\end{array}$ & FF (Tech. fix $)$ & ERDA & Edison Electric Inst. \\
\hline & Lovins & $v H$ and $W-$ Lovins & $E R D A$ & \\
\hline 1978 & $\begin{array}{c}33 \\
\text { Stcinhart } \\
\text { (for 2050) }\end{array}$ & $\begin{array}{c}63-77 \\
\text { CONAES panel } \\
\text { (for 2010) }\end{array}$ & $\begin{array}{c}95-100 \\
\text { CONAES, DOE-IEA }\end{array}$ & $\begin{array}{c}123-124 \\
R D E-\text { Ralph Lapp }\end{array}$ \\
\hline
\end{tabular}

Energy forecasts have been falling in many countries, not only the UK. Amory Lovins has communicated this table of US forecasts for the year 2000 , produced by various bodies over the last six years. "Read diagonally, the matrix has considerable predictive power" says Lovins. The September 1978 Department of Energy forecasts were not known when the table was first prepared. However, there is considerable subjective judgement involved in the choice of columns and of forecasts to fit them. Read literally, the matrix predicts that the conventional 1980 US forecast for the year 2000 will be some 70 quads, less than 1975 consumption.

Abbreviations used: AEC, Atomic Energy Commission; FF, Ford Foundation; ERDA, Energy Research and Development Administration; $\mathrm{vH}$ and W, von Hippel and Williams; CONAES, the Committee on Nuclear and Alternative Energy Systems of the US National Research Council; and DOE, Department of Energy. In 1976 Lovins' two forecasts were private (75q) and public (95q, published in Foreign Affairs). In 1978 the CONAES panel used three scenarios, as did the DOE (varying with projected oil price).

\section{Black year for Soviet refusniks}

1978 was, in general, a black year for Soviet refusnik scientists, marked by increasing harassment and the imprisonment or exile of a number of the best-known of them. However, the year ended on a note of partial triumphin the last week of December the "Sunday seminar" for refusniks achieved its long-standing aim of an international meeting with the participation of scientists from USA, France and the UK.

Inevitably a number of the intending foreign visitors failed to receive the necessary visas. Five of the eight would-be participants from the US had their visas revoked-evoking a statement of censure from the Committee of Concerned Scientists saying that it "found it unconscionable for the USSR to seek to prevent American scientists from engaging in scientific discusşions with Soviet colleagues". The conference, it claimed, was "an excellent example of the kind of unofficial, nongovernmental exchanges provided for by the Helsinki Final Act."

"Non-governmental" exchanges do not fit easily into the Soviet concept of science, and previous attempts of the seminar group to hold an international meeting were less successful. In 1974, no foreign visas were issued and the leading Soviet participants were arrested. Nevertheless, the proceedings of the "Conference that never was" were published in the regular manner, and limited foreign participation was permitted in the April 1977 meeting to commemorate the fifth anniversary of the founding of the seminar.

The apparent acquiescense of the Soviet authorities with regard to last month's meeting seem due rather to international pressure than to any change of heart. Continuing routine surveillance of the venue-the flat of Viktor Brailovskii-during the seminar, and a thorough police search with confiscation of his recent scientific material and his Lenin library ticket made this clear. A number of other intending participants suffered like harassments.

Nevertheless, the meeting itself took place. The main purpose of last months gathering was to bring the refusniks abreast of recent Western developments.

The chosen title "collective phenomena" allowed a wide range of subjects. The US participants presented work in statistical physics and vortex motion in superfluid ${ }^{4} \mathrm{He}$, while the French contributions ranged over crystal physics, axiomatic quantum field theory, one-dimensional conductors, and what one participant described as a "very pretty" result in percolation theory. Since this last contribution required no specialist background, it was of particular value to the refusniks, many of whom have inevitably fallen irrevocably behind in their original field, and who therefore wish to extend their acquaintance with other subjects.

Local contributions were, understandably, somewhat hampered by the extremely restrictive nature of refusnik life-lack of access to experimental facilities and to new results in particular. Nevertheless, a wide range of subjects was attempted, including solitons, plasma physics, and quantum field theory. Yurii Orlov, one of the few non-Jewish members of the original seminar group, could not be present in person-he is at present serving a 12-year sentence for "antiSoviet agitation and propaganda". A paper of his on "Wave logic", an alternative to conventional two-valued logic, more appropriate to quantum mechanics was presented in absentia.

Another gentile who has always taken a keen interest in the Seminar, is academician Andrei Sakharov. To the delight of all participants, Sakharov attended the first session. Other notable Soviet participants included Aleksandr Lerner, Grigorii Rozenshtein, Yurii Fishman, Yurii Gol'fand and Yakov Al'pert. 